\title{
SISTEM PEMASARAN NENAS DI KECAMATAN CIJERUK, KABUPATEN BOGOR
}

\author{
Murni Anggraeni ${ }^{1)}$, dan Suharno ${ }^{2)}$ \\ ${ }^{1,2)}$ Departemen Agribisnis, Fakultas Ekonomi dan Manajemen, Institut Pertanian Bogor \\ ${ }^{1)}$ murni.anggraeni@gmail.com
}

\begin{abstract}
Bogor pineapple is the leading commodity ini Cijeruk subdisctrict, Bogor Regency, which is expected to increase the potential resource of local economy. The marketing of Bogor pineapple faces some constraints, such as (1) the large gap between farm price and retail price, (2) the weak bargaining position of farmers in the marketing chain, (3) the role of farmers group that have not been optimalized, (4) the farm location that is difficult to access, and (5) the competition with pineappples from outside Bogor. The purpose of this study was to determine the marketing channels formed in the marketing system of Bogor pineapple and the efficiency of each marketing channels so that we can provide the most efficient for pineapple farmers. The method of data collection is snowball sampling as many as 30 farmers to local traders, wholesalers, and retailers. Results of this research is that there are 10 marketing channel patterns formed. Seen from the value of marketing margin, farmer's share, ratio of profit to cost, and the ease of access, the relatively efficient channels are channel 3 and 6. Both channels are the most selected marketing channels, which respectively amounted to 2,33 percent and 16,66 percent of farmers.
\end{abstract}

Keyword(s): pineapple, marketing system, marketing efficiency

\begin{abstract}
ABSTRAK
Nenas Bogor adalah komoditas unggulan Kecamatan Cijeruk, Kabupaten Bogor, yang dapat diharapkan dapat meningkatkan potensi sumberdaya ekonomi lokal. Pemasaran nenas Bogor menghadapi beberapa kendala, seperti (1) selisih yang besar antara harga di tingkat petani dengan harga di tingkat konsumen, (2) posisi tawar petani yang lemah dalam rantai pemasaran, (3) belum optimalnya peran kelompok tani, (4) lokasi kebun yang sulit diakses, serta (5) adanya persaingan dengan nenas dari luar Bogor. Penelitian ini dilakukan untuk mengetahui saluran pemasaran yang terdapat sistem pemasaran nenas Bogor dan mengetahui efisiensi saluran tersebut untuk memberikan alternatif saluran pemasaran yang paling efisien bagi petani. Metode pengambilan data dilakukan dengan cara snowball sebanyak 30 petani responden lalu ke pedagang pengumpul desa, pedagang besar, dan pedagang pengecer. Hasil penelitian ini adalah terdapat 10 pola saluran pemasaran yang terbentuk. Dilihat dari besarnya marjin pemasaran, farmer's share, rasio keuntungan terhadap biaya, serta kemudahan akses, saluran yang relatif efisien adalah saluran 3 (petani - pedagang pengumpul desa - konsumen akhir) dan 6 (petani pedagang pengumpul desa - pengolah). Kedua saluran pemasaran tersebut juga merupakan saluran pemasaran yang paling banyak dipilih oleh petani yaitu masing masing sebesar 2,33 persen dan 16,66 persen petani.
\end{abstract}

Kata Kunci: nenas, sistem pemasaran, efisiensi pemasaran 


\section{Latar Belakang}

Hortikultura merupakan salah satu subsektor unggulan dalam sektor pertanian di Indonesia. Hal tersebut terlihat pada nilai kontribusi hortikultura terhadap PDB Indonesia yang terus meningkat. Dari tahun 2005 ke 2009, PDB nasional hortikultura mengalami peningkatan sebesar 44,13 persen, yakni dari 61,79 triliun rupiah menjadi 89,057 triliun rupiah. Komoditas hortikultura memiliki nilai ekonomi yang tinggi dan pembudidayaannya perlu dilakukan secara intensif dengan keterampilan tinggi. Tanaman hortikultura cocok untuk diusahakan di Indonesia. Hortikultura di antaranya terdiri dari sayur-sayuran, buah-buahan, tanaman biofarmaka, dan tanaman hias.

Berdasarkan data yang bersumber dari Pusat Data dan Informasi Kementerian Pertanian, diperoleh informasi bahwa produksi buah di Indonesia mengalami peningkatan hampir di setiap tahunnya. Pada periode 2002-2012, penurunan produksi pada sub sektor buah hanya terjadi pada tahun 2009 dan 2010. Pada tahun 2009, produksi buah Indonesia adalah sebesar 6.708.202 ton atau mengalami penurunan sebesar 2,91 persen dibandingkan pada tahun sebelumnya yang menghasilkan produksi buah sebesar 6.909.653 ton. Sedangkan pada tahun 2010, produksi buah dalam negeri sebesar 5.457.101 ton atau mengalami penurunan produksi sebesar 18,65 persen jika dibandingkan dengan produksi tahun sebelumnya yang mencapai 6.708.202 ton.
Saat ini buah telah menjadi komoditas perdagangan internasional. Meski terhitung kecil, ekspor buah Indonesia selalu meningkat setiap tahun. Beberapa jenis buah unggulan Indonesia yang dipasarkan di pasar internasional antara lain jeruk, pisang, mangga, nenas, manggis, rambutan, serta melon dan semangka. Saat ini buah lokal yang paling diminati di pasar internasional adalah nenas.

Nenas merupakan buah dengan volume ekspor tertinggi di Indonesia pada periode 2008-2012. Volume ekspor nenas di tahun 2012 mengalami penurunan yang signifikan dibandingkan volume ekspor nenas di tahun 2008, yakni turun sebesar 5,28 persen. Hal ini disebabkan karena dibandingkan dengan nenas segar, Indonesia lebih besar mengekspor nenas dalam bentuk olahan. Luas panen, produksi, dan produktivitas nenas di Indonesia cenderung mengalami peningkatan. Selain untuk diekspor, nenas juga memiliki pasar domestik yang potensial. Berdasarkan data konsumsi nenas di Indonesia dari Survei Sosial Ekonomi Nasional (Susenas), meskipun minat masyarakat untuk mengonsumsi nenas segar semakin menurun, masyarakat tetap suka mengonsumsi mengonsumsi nenas setelah diolah menjadi nenas kaleng, manisan nenas, selai nenas, dodol nenas, keripik nenas, dan lain-lain.

Berdasarkan rata-rata produksi nenas tahun 2008-2012, Jawa Barat merupakan salah satu daerah penghasil nenas terbesar di Indonesia dengan kontribusi sebesar 22,72 persen dengan rata-rata produksi 350,77 ton. Beberapa daerah penghasil nenas di Jawa Barat 
antara lain Kabupaten Subang, Bogor, Tasikmalaya, Cianjur, dan Ciamis.

Kabupaten Bogor merupakan daerah penghasil nenas terbesar kedua setelah Subang. Meski begitu, persentase ratarata peningkatan produksi nenas per tahun Kabupaten Bogor lebih tinggi dibandingkan kabupaten lainnya, yaitu 48 persen pada periode 2008-2012. Departemen Pertanian dalam Program Pengembangan Sentra Produksi Hortikultura di Jawa Barat telah menetapkan Bogor sebagai salah satu daerah yang memiliki potensi untuk dikembangkan. Kecamatan Cijeruk merupakan daerah penghasil nenas terbesar di Kabupaten Bogor. Badan Perencanaan dan Pengembangan Daerah (Bappeda) Kabupaten Bogor, sebagai salah satu instansi yang memiliki fungsi perencanaan pembangunan daerah, mengembangkan nenas sebagai komoditas asli dari Kabupaten Bogor, terutama sebagai salah satu potensi sumberdaya lokal yang ada di Kecamatan Cijeruk. Penyebaran produksi nenas di Kecamatan Cijeruk di antaranya di Desa Cipelang, Sukaharja, Palasari, Cijeruk, dan Tajur Halang.

\section{Perumusan Masalah}

Usahatani nenas bogor merupakan mata pencaharian utama para petani di Kecamatan Cijeruk yang telah dilakukan turun temurun. Kecamatan Cijeruk menjadi sentra lokasi pengembangan nenas Bogor. Produk utamanya adalah buah segar yang sebagian besar dijual untuk bahan baku asinan Bogor (Bappeda Kabupaten Bogor, 2013). Secara umum, kegiatan usahatani nenas bogor tersebut dilakukan untuk memperoleh keuntungan dari kegiatan pemasaran agribisnis. Dalam memasarkan produknya, petani nenas di Kecamatan Cijeruk menghadapi kendala-kendala pemasaran.

Harga yang diterima oleh petani jauh lebih rendah dibandingkan harga akhir di konsumen. Berdasarkan hasil wawancara dengan petani responden pada bulan Maret - Mei 2015, sebagian besar petani menjual produknya ke pedagang pengumpul desa dengan harga rata-rata Rp 1785 per buah. Sementara itu, harga di tingkat konsumen berkisar antara Rp 3 000 - Rp 5625 per buah.

Komoditas pertanian seperti nenas memiliki sifat yang mudah rusak sehingga, untuk meminimalisasi kemungkinan kerusakan yang terjadi, petani perlu menjual produknya sesegera mungkin. Menurunnya kualitas nenas akibat lamanya proses pemasaran, terlebih dengan penanganan pasca panen yang kurang baik, akan berdampak pada penurunan harga jual nenas. Hal ini menyebabkan posisi tawar petani lemah dalam rantai pemasaran, sehingga petani menjadi price taker agar proses pemasaran dapat dilakukan segera. Petani juga tidak memiliki informasi pasar yang lengkap, padahal tinggi rendahnya harga jual ditentukan oleh mekanisme pasar. Selain itu, petani memiliki ketergantungan terhadap pedagang pengumpul karena masalah utang-piutang sehingga petani memerlukan alternatif saluran pemasaran yang lebih menguntungkan. Peran kelompok tani juga belum optimal dalam membantu petani memasarkan produknya. Akibatnya, petani tidak mampu mendapatkan harga yang lebih tinggi dan 
berimplikasi pada penerimaan petani nenas.

Permasalahan yang juga dialami oleh petani nenas Bogor yaitu lokasi kebun yang sulit dijangkau. Jalan yang dilalui curam, berbatu, serta cukup jauh dari jalan raya. Beberapa wilayah masih dapat dijangkau oleh mobil dan motor, namun ada yang hanya bisa ditempuh dengan berjalan kaki. Selain itu, terdapat persaingan dengan nenas yang berasal dari luar Bogor. Meskipun nenas Bogor tidak kalah dari segi rasa, neenas yang berasal dari luar Bogor memiliki harga yang tidak jauh berbeda dengan ukuran yang lebih besar.

Petani menghadapi saluran pemasaran yang berbeda-beda dalam memasarkan produknya. Perbedaan saluran pemasaran ini mengakibatkan perbedaan harga jual, kentungan dan biaya-biaya yang harus dikeluarkan. Hal ini akan berpengaruh pada harga nenas di tingkat konsumen akhir. Panjangnya rantai pemasaran dikhawatirkan membuat harga nenas di tingkat konsumen akhir semakin mahal dan kualitas tidak terjamin. Petani nenas pun belum tentu memperoleh bagian (share) yang sesuai dan merata dari harga produk akhir yang mahal tersebut.

Analisis efisiensi pemasaran nenas Bogor dilakukan untuk mengetahui kondisi riil di lapangan terkait pelaksanaan sistem pemasaran nenas Bogor dan melihat tingkat efisiensi operasional saluran pemasaran yang terbentuk dalam sistem pemasaran nenas di Kecamatan Cijeruk.

Sehingga perumusan masalah yang terdapat dalam penelitian ini yaitu:
1. Bagaimana saluran pemasaran yang terbentuk dalam sistem pemasaran nenas Bogor di Kecamatan Cijeruk, Kabupaten Bogor?

2. Dari saluran pemasaran nenas Bogor yang terbentuk, saluran mana yang relatif lebih efisien dilihat dari segi efisiensi operasional?

\section{Tujuan Penelitian}

Adapun tujuan penelitian ini adalah:

1. Menganalisis saluran pemasaran yang terbentuk dalam sistem pemasaran nenas Bogor di Kecamatan Cijeruk, Kabupaten Bogor.

2. Menganalisis tingkat efisiensi operasional saluran pemasaran nenas Bogor yang terbentuk di Kecamatan Cijeruk, Kabupaten Bogor.

\section{Manfaat Penelitian}

Adapun manfaat yang diharapkan dari adanya penelitian ini adalah sebagai berikut:

1. Sebagai informasi bagi petani dan lembaga pemasaran untuk meningkatkan kerjasama dan pendapatannya dalam proses pemasaran nenas Bogor.

2. Bahan informasi dan kajian ilmiah dalam perencanaan kebijakan sosial ekonomi komoditas nenas dalam mencari alternatif pemecahan masalah pemasaran nenas Bogor, khusunya di wilayah Kabupaten Bogor.

3. Bagi akademisi, sebagai tambahan ilmu pengetahuan untuk memperluas wawasan dan dapat digunakan sebagai referensi penelitian. 


\section{METODE PENELITIAN}

\section{Lokasi dan Waktu}

Penelitian mengenai sistem pemasaran nenas Bogor dilakukan di Kecamatan Cijeruk, Kabupaten Bogor. Pemilihan lokasi ini dilakukan secara sengaja (purposive) dengan pertimbangan bahwa Kabupaten Bogor merupakan daerah penghasil nenas terbesar di Jawa Barat serta merupakan salah satu daerah pengembangan sentra produksi nenas. Kecamatan Cijeruk merupakan sentra pengembangan sekaligus penghasil nenas Bogor terbesar di Kabupaten Bogor yang rata-rata memiliki tanaman nenas yang berada pada masa produktif.

\section{Jenis dan Sumber Data}

Data yang dikumpulkan dalam penelitian terdiri atas data primer dan data sekunder, baik data yang bersifat kuantitatif maupun kualitatif. Data primer diperoleh secara langsung melalui mekanisme wawancara dan observasi selama penelitian. Wawancara dilakukan dengan bantuan kuesioner sebagai panduan utama dalam menjalankan proses wawancara tersebut.

Data sekunder diperoleh dari tinjauan pustaka dan studi literatur serta beberapa model penelitian terdahulu yang berkaitan dengan penelitian ini. Data sekunder yang menyangkut data produksi diperoleh dari Direktorat Tanaman Pangan dan Hortikultura, Badan Pusat Statistika Kabupaten Bogor, Pusat data dan Informasi Kementerian Pertanian, serta Dinas pertanian Kabupaten Bogor, serta literatur lainnya yang berkaitan dengan objek penelitian

\section{Metode Penentuan Sampel}

Pengambilan sampel, baik petani maupun pedagang, dilakukan dengan snowball method yaitu dengan cara mengikuti alur pemasaran hingga produk sampai ke konsumen dan menelusuri saluran pemasaran buah nenas di daerah penelitian berdasarkan informasi yang di dapat dari pelaku pasar yaitu mulai dari tingkat petani sampai pedagang pengecer. Hal ini untuk menghindari lembaga pemasaran yang dianalisis efisiensi pemasarannya ternyata tidak menggunakan saluran pemasaran yang telah terbentuk sebelumnya.

\section{Metode Pengumpulan Data}

Pengumpulan data dalam penelitian kali ini menggunakan metode observasi, wawancara, dan diskusi. Metode observasi dilakukan dengan melakukan pengamatan langsung selama kegiatan penelitian di Kecamatan Cijeruk untuk memperoleh informasi dan data pendukung baik dari petani, penduduk, ataupun aparatur pemerintah. Metode wawancara dilakukan dengan mengajukan beberapa pertanyaan yang telah disusun dalam kuesioner.

\section{Metode Pengolahan Data}

Sistem pemasaran pertanian merupakan kesatuan sistem dari aktivitas ekonomi yang dimulai dari proses produksi barang-barang pertanian sampai dengan tingkat konsumsi. Penelitian ini menganalisis aktivitas bisnis yang terjadi pada nenas Bogor di Kecamatan Cijeruk mulai dari petani produsen primer hingga ke tangan konsumen akhir. 
Pengolahan data pada penelitian ini menggunakan analisis kualitatif yang dilakukan untuk menggambarkan saluran dan lembaga pemasaran, fungsi pemasaran, serta struktur dan perilaku pasar dari sistem pemasaran nenas Bogor di Kecamatan Cijeruk, Kabupaten Bogor.

Selain itu, analisis kuantitatif juga dilakukan pada penelitian ini untuk melihat keragaan pasar yang dilihat dari nilai marjin pemasaran, farmer's share, serta rasio keuntungan terhadap biaya. Data kuantitatif diperoleh melalui kuesioner yang telah diisi oleh responden dan selanjutnya akan dihitung dengan alat bantu Microsoft Excel 2010 dan kalkulator .

\section{Struktur, Perilaku, dan Keragaan Pasar}

Struktur pasar (market structure) dapat diartikan sebagai tipe atau jenisjenis pasar dan merupakan tingkat persaingan pasar. Secara garis besar, terdapat dua kelompok struktur pasar, yaitu pasar persaingan sempurna (perfect competition) dan pasar tidak bersaing (monopoli atau monopsoni), sedangkan jenis lainnya merupakan struktur pasar dengan jenis di antara kedua struktur tersebut (monopolistik, oligopoli, dan duopoli). Beberapa ukuran untuk melihat sruktur pasar antara lain: (1) market concentration (konsentrasi pasar), (2) exit-entry (kebebasan perusahaan untuk keluar atau masuk ke dalam industry), serta (3) product differentiation (diferensiasi produk).

Perilaku pasar (market conduct) adalah pola tingkah laku dari lembaga pemasaran yang menyesuaikan dengan struktur pasar di mana lembaga tersebut melakukan kegiatan pembelian dan penjualan. Perilaku pasar dicerminkan dari bagaimana praktik jual beli dilakukan antar lembaga pemasaran, termasuk produsen dan konsumen. Halhal yang diamati terkait analisis perilaku pasar antara lain praktik jual beli nenas Bogor di Kecamatan Cijeruk, sistem penetapan harga, sistem pembayaran, dan kerja sama antar lembaga pemasaran yang terjadi.

Sementara keragaan pasar merupakan hasil akhir struktur dan perilaku pasar. Keragaan pasar (market performance) mengungkapkan tentang tingkat profit dan efisiensi dari suatu sistem pasar. Ukuran yang digunakan untuk menilai keragaan pasar tersebut adalah besaran marjin pemasaran, farmer's share, dan rasio keuntungan terhadap biaya.

\section{Marjin Pemasaran}

Besarnya marjin merupakan penjumlahan dari biaya-biaya pemasaran yang dikeluarkan dan keuntungan yang oleh lembaga pemasaran. Dirumuskan:

$M \mathrm{i}=P$ si $-P$ bi

dimana :

Mi : Marjin pemasaran di tingkat ke-i

Psi : Harga jual pasar di tingkat ke-i

Pbi : Harga beli pasar di tingkat ke-i

Marjin pemasaran juga dapat diperoleh dari penjumlahan biaya dan keuntungan pada masing-masing lembaga pemasaran. Secara matematis dapat dirumuskan sebagai berikut:

$\mathrm{Mi}=\mathrm{Ci}+\pi \mathrm{i}$ 
dimana :

$\mathrm{Ci}=$ biaya lembaga pemasaran di tingkat ke-i

$\pi \mathrm{i}=$ keuntungan lembaga pemasaran di tingkat ke-i

Dari persamaan (1) dan (2), maka diperoleh persamaan sebagai berikut:

$$
\text { Psi }-\mathrm{Pbi}=\mathrm{Ci}+\pi \mathrm{i}
$$

Dengan demikian keuntungan lembaga pemasaran di tingkat ke-i sebesar:

$$
\pi \mathrm{i}=\mathrm{Psi}-\mathrm{Pbi}-\mathrm{Ci}
$$

Sumber : Asmarantaka (2012)

\section{Farmer's Share}

Farmer's share merupakan perbandingan antara harga di tingkat petani nenas dengan di tingkat konsumen. Ini merupakan porsi dari nilai yang dibayar konsumen akhir yang diterima oleh petani dalam bentuk persen. Secara matematis farmer's share dapat dirumuskan sebagai berikut:

$$
\mathrm{Fs}=\frac{P f}{P r} \times 100 \%
$$

dimana:

Fs = farmer's share

$\mathrm{Pf}=$ harga ditingkat produsen

$\operatorname{Pr}=$ harga yang dibayarkan oleh konsumen akhir

Sumber : Asmarantaka (2012)

\section{Analisis Rasio Keuntungan terhadap Biaya}

Tingkat efisiensi sebuah sistem pemasaran dapat dilihat dari rasio keuntungan terhadap biaya pemasaran. Apabila dengan semakin meratanya rasio keuntungan terhadap biaya pemasaran maka secara teknik sistem pemasaran tersebut efisien. Secara matematis rasio keuntungan dan biaya pemasaran dirumuskan sebagai berikut:

Rasio keuntungan terhadap biaya $=\frac{L i}{C i}$

dimana:

$\mathrm{Li}=$ keuntungan lembaga pemasaran

$\mathrm{Ci}=$ biaya Pemasaran

Sumber : Asmarantaka (2012)

HASIL DAN PEMBAHASAN

Analisis Lembaga dan Saluran Pemasaran

Berdasarkan penelitian ini terdapat 10 saluran pemasaran nenas dari Kecamatan Cijeruk, yaitu:

1. Saluran 1: Petani $\rightarrow$ Konsumen Akhir.

2. Saluran 2: Petani $\rightarrow$ Pengolah.

3. Saluran 3: Petani $\rightarrow$ PPD $\rightarrow$ Konsumen Akhir.

4. Saluran 4: Petani $\rightarrow$ PPD $\rightarrow$ Pedagang Besar $\rightarrow$ Pengecer $\rightarrow$ Konsumen.

5. Saluran 5: Petani $\rightarrow$ PPD $\rightarrow$ Pedagang Besar $\rightarrow$ Pengolah

6. Saluran 6: Petani $\rightarrow$ PPD $\rightarrow$ Pengolah.

7. Saluran 7:

Petani $\rightarrow$ PPD $\rightarrow$ Pengecer $\rightarrow$ Konsumen.

8. Saluran 8: Petani $\rightarrow$ Pedagang Besar $\rightarrow$ Pengecer $\rightarrow$ Konsumen .

9. Saluran 9: Petani $\rightarrow$ Pedagang Besar $\rightarrow$ Pengolah.

10.Saluran 10:

Petani $\rightarrow$ Pengecer $\rightarrow$ Konsumen.

Jumlah petani pada masing-masing saluran pemasaran nenas di Kecamatan Cijeruk beserta persentase pemilihan saluran dan volume nenas pada masingmasing saluran dapat dilihat pada Tabel 1 dan pola saluran pemasaran nenas di 
Kecamatan Cijeruk dapat dilihat pada Lampiran 1.

Tabel 1. Jumlah Petani, Persentase Pemilihan, dan Persentase Volume Nenas pada MasingMasing Saluran

\begin{tabular}{ccrr}
\hline Saluran & $\begin{array}{l}\text { Jumlah } \\
\text { Petani } \\
\text { (Orang) }\end{array}$ & $\begin{array}{l}\text { Persentase } \\
\text { Pemilihan } \\
\text { Saluran(\%) }\end{array}$ & $\begin{array}{l}\text { Persentase } \\
\text { Volume } \\
\text { Nenas (\%) }\end{array}$ \\
\hline 1 & 1 & 3,33 & 2,16 \\
2 & 1 & 3,33 & 1,82 \\
3 & 7 & 23,33 & 9,44 \\
4 & 2 & 6,66 & 3,99 \\
5 & 3 & 10 & 11,3 \\
6 & 5 & 16,66 & 16,88 \\
7 & 3 & 10 & 9,12 \\
8 & 1 & 3,33 & 5,36 \\
9 & 2 & 6,66 & 8,1 \\
10 & 5 & 16,66 & 31,94 \\
\hline Total & $\mathbf{3 0}$ & $\mathbf{1 0 0}$ & $\mathbf{1 0 0}$ \\
\hline
\end{tabular}

Petani lebih banyak menjual nenasnya kepada PPD. Hal ini antara lain disebabkan oleh kemudahan melakukan transaksi serta keterikatan petani dengan PPD. Sebagain besar petani menjual hasil panennya kepada PPD yang sama setiap kali panen karena sudah saling percaya. Pembayaran hasil panen tidak terlalu lama, yaitu dibayar langsung atau dibayar sebagian hingga produk laku terjual yang umumnya hanya membutuhkan waktu satu hari. Selain itu, keterikatan petani dengan PPD juga disebabkan karena bantuan utang yang diberikan PPD ketika petani menunggu musim panen dengan jangka waktu 2-3 bulan.

Dibandingkan dengan penelitian sebelumnya, yang juga mengenai sistem pemasaran nenas Bogor seperti yang dilakukan Sihombing (2010) dan Rahmawati (2013), terlihat bahwa dari tahun ke tahun semakin banyak pola saluran pemasaran yang dapat dipilih oleh petani, yaitu tiga, lima, kemudian sepuluh saluran. Hal ini berarti petani memiliki potensi akses pasar yang baik. Meski demikian, tidak semua petani dapat mengakses saluran pemasaran yang lebih menguntungkan karena petani terikat utang-piutang dengan pedagang pengumpul langganannya.

\section{Analisis Fungsi Pemasaran}

Setiap lembaga pemasaran yang terkait dengan pemasaran nenas dari Kecamatan Cijeruk melakukan fungsi pemasaran yang berbeda-beda. Lampiran 2 menunjukkan fungsi-fungsi pemasaran yang dilakukan oleh masing-masing lembaga pemasaran. Fungsi - fungsi pemasaran yang dilakukan oleh lembaga pemasaran antara lain fungsi pertukaran, fungsi fisik, dan fungsi fasilitas. Fungsifungsi pemasaran yang dilakukan masih tergolong sederhana. Petani sudah melakukan fungsi sortasi atau grading berdasarkan ukuran untuk memudahkan penetapan harga, namun harga yang digunakan umumnya harga grosir.

Pada penelitian Rahmawati (2013), petani nenas yang berada di Desa Cipelang, Kabupaten Cijeruk tergabung dalam kelompok tani yang memiliki gudang penyimpanan di luar areal kebun untuk menyimpan hasil panen petani serta menjalankan fungsi informasi pasar dengan menginformasikan perkembangan harga. Pada saat penelitian ini dilakukan, kedua fungsi tersebut sudah tidak lagi dilakukan karena kelompok tani tersebut sudah tidak berjalan seperti sebelumnya. 


\section{Analisis Struktur Pasar}

Pengamatan di lapang menunjukkan bahwa struktur pasar nenas Bogor yang terjadi mendekati struktur pasar persaingan murni. Ciri-ciri dari struktur pasar persaingan murni yang terdapat dalam pasar nenas Bogor antara lain banyaknya jumlah produsen dan konsumen, sifat produk yang homogen dan tidak terdapat diferensiasi, petani sebagai penerima harga (price taker), serta rendahnya hambatan bagi seseorang yang ingin masuk pasar nenas Bogor.

Nenas memiliki banyak produsen (petani) dan banyak konsumen, sehingga untuk dapat menjual nenas Bogor, terdapat persaingan antar penjual. Tidak seperti kebanyakan sektor ekonomi lainnya, petani menjual produk mereka dengan harga grosir tetapi membayar harga eceran untuk input produksi mereka (Magdof et al. 2000 dalam Carolan 2012). Selama puluhan tahun, harga input seperti bahan bakar, benih, pestisida, dan pupuk telah mengalami peningkatan. Oleh karena itu, petani seperti 'diperas' pada dua sisi, sebagai akibat dari harga di tingkat petani yang stabil atau menurun dan biaya input yang terus meningkat, atau dikenal dengan istilah double squeeze phenomenon. Hal ini juga terjadi pada produsen nenas Bogor. Persaingan antar produsen atau penjual menyebabkan produsen atau penjual tidak dapat menentukan harga (price taker) yang juga merupakan bentuk dari struktur pasar persaingan. Di satu sisi, sebagian petani responden mengaku tidak mampu menggunakan pupuk karena tidak memiliki modal yang cukup. Di sisi lain, nenas yang tidak menggunakan pupuk produktivitasnya lebih rendah sehingga buah yang dihasilkan lebih sedikit dibandingkan nenas yang dipupuk. Selain itu, nenas yang rata-rata umurnya sudah di atas lima tahun tersebut menghasilkan buah yang ukurannya semakin mengecil sehingga harga nenas pun menjadi semakin murah.

Sifat produk dalam pasar masih homogen, tidak terdapat perbedaan atau diferensiasi antar nenas Bogor, kecuali ukurannya yang terdiri dari ukuran besar, sedang, dan kecil. Namun, selain pengecer, petani dan lembaga pemasaran lainnya menjual nenas Bogor secara grosir sehingga harganya menjadi sama rata. Jika dibandingkan dengan nenas dari luar Bogor, berdasarkan keterangan dari produsen dan pedangang, nenas Bogor memiliki keunikan yaitu ukuran yang lebih kecil, kandungan air yang lebih sedikit, serta rasa yang lebih manis dan enak. Nenas Bogor juga tidak menimbulkan rasa gatal di lidah jika dikonsumsi langsung.

Hambatan bagi seseorang yang ingin masuk dalam pasar atau industri nenas Bogor relatif rendah, baik untuk menjadi petani maupun pedagang. Tetapi, untuk dapat menjadi pedagang pengumpul desa dan pedagang besar dibutuhkan jaringan sosial yang kuat untuk dapat masuk ke pasar atau industri nenas Bogor. Hal ini disebabkan pedagang pengumpul desa maupun pedagang besar sudah memiliki langganan masing-masing. Selain itu juga membutuhkan modal yang cukup banyak untuk dapat membeli nenas Bogor dalam kuantitas yang besar. 


\section{Perilaku Pasar}

Perilaku pasar dicerminkan dari bagaimana praktek jual beli dilakukan antar lembaga pemasaran termasuk produsen dan konsumen. Hal-hal yang diamati terkait analisis perilaku pasar antara lain praktik jual beli nenas Bogor di Kecamatan Cijeruk, sistem penetapan harga, sistem pembayaran, dan kerjasama antar lembaga pemasaran yang terjadi seperti yang diperlihatkan pada Lampiran 3.

\section{Praktik Penjualan dan Pembelian Nenas di Kecamatan Cijeruk}

Petani nenas umumnya menjual produknya kepada pedagang pengumpul desa (PPD) yang telah dipercaya atau pedagang pengumpul desa yang memiliki hubungan kekerabatan. Kegiatan pemasaran nenas dimulai sejak panen. Kegiatan pemanenan dilakukan pada pagi hari dan dilakukan sendiri oleh petani. Sebagian petani bahkan menyerahkan kegiatan pemanenan kepada PPD yang telah menjadi langganan, dengan biaya angkut tetap ditanggung oleh petani. Sebagian besar petani menjual hasil panennya ke PPD. Hal ini disebabkan karena adanya ikatan kerja sama antara petani dengan PPD walaupun tidak bersifat resmi. Selain itu, PPD seringkali memberikan pinjaman kepada petani yang tidak memiliki pendapatan selama menunggu masa panen. Hal ini juga menciptakan suatu ikatan antara petani dengan PPD sehingga ketika panen petani akan menjual nenasnya kepada PPD tersebut.

Selanjutnya, PPD menjual nenas ke pedagang besar, pedagang eceran, atau pengolah. PPD yang menjual nenas kepada pedagang besar telah memiliki langganan, sehingga PPD tidak kesulitan menemukan pembeli ketika mengantarkan nenas ke pasar. Sementara itu, PPD yang menjual produknya kepada pengecer tidak terpaku pada satu orang saja. PPD akan menjual produknya kepada pengecer yang datang dan bersedia membayar dengan harga yang sesuai. PPD yang menjual produknya ke pengolah adalah pegawai dari perusahaan pengolah tersebut. Harga yang ditetapkan tidak mengikuti harga pasar, melainkan harga kontrak, sehingga relatif stabil. Sementara itu, dalam membeli nenas, pedagang pengecer maupun konsumen cenderung memilih pedagang yang menjual nenas dengan harga yang lebih rendah.

Selain melalui PPD, terdapat petani yang yang menjual produknya ke pedagang besar, pengecer, maupun langsung ke pengolah dan konsumen akhir. Dilihat dari banyaknya saluran yang terbentuk, petani memiliki potensi akses pasar yang baik.

\section{Sistem Penentuan Harga}

Penetapan harga nenas di tingkat petani, pedagang pengumpul desa (PPD), pedagang besar maupun pedagang pengecer mengacu kepada harga yang berlaku di pasar. Di pasar, pedagang besar menetapkan harga berdasarkan jumlah pasokan yang masuk dan jumlah permintaan konsumen. Saat pasokan nenas berlimpah, maka harga akan turun. Ditambah lagi jika banyak nenas yang berasal dari luar Bogor masuk ke pasar. Karena sifat produk hortikultura seperti nenas yang musiman, tidak tahan lama, 
serta sulit disimpan, pada saat pasokan nenas berlimpah petani tidak memiliki pilihan yang lebih baik karena produk harus cepat terjual. Petani terpaksa menjual produknya dengan sangat murah. Harga nenas di tingkat petani ditentukan oleh PPD karena petani kurang memiliki informasi pasar. Ikatan utang antara petani dengan PPD menjadi salah satu penyebab posisi tawar petani lebih rendah dibandingkan PPD. Dalam hal ini, kelompok tani yang ada belum berperan dalam membantu petani meningkatkan posisi tawarnya maupun membantu melakukan pengembangan produk dengan melakukan pengolahan untuk meningkatkan nilai jual nenas. Sementara itu, penentuan harga antara PPD dengan pedagang besar dan pengecer biasanya ditetapkan secara tawar menawar. Namun posisi tawar PPD lebih kuat karena sebagian besar nenas yang dihasilkan petani dikuasai oleh PPD. Sementara itu, penentuan harga antara pengecer dengan pedagang besar ditetapkan secara tawar menawar, begitu pula antara pengecer dengan konsumen. Untuk penetapan harga kepada pengolah, seperti yang telah disebutkan sebalumnya, harga yang digunakan adalah harga kontrak sehingga relatif stabil. Selain pengecer, meskipun telah dilakukan sortasi, petani dan lembaga pemasaran lainnya menjual nenas Bogor secara grosir sehingga harganya menjadi sama rata. Padahal harga eceran untuk nenas ukuran kecil dan nenas ukuran besar sangat berbeda. Untuk menyiasati hal tersebut, dalam menjual nenasnya mereka mencampurkan lebih banyak nenas kecil daripada nenas besar.

\section{Sistem Pembayaran}

Pada pemasaran nenas di Kecamatan Cijeruk terdapat tiga macam sistem pembayaran yang dilakukan yaitu:

1. Sistem pembayaran tunai.

Sistem pembayaran tunai adalah pembayaran penuh saat proses transaksi terjadi. Sistem pembayaran tunai dipilih jika kuantitas yang dibeli oleh pedagang tidak terlalu banyak atau pedagang memiliki cukup modal. Pembayaran tunai dilakukan oleh petani pengumpul desa (PPD) dengan petani, pedagang besar dengan PPD dan petani, pengecer dengan petani, PPD, dan pedagang besar, pengolah dengan petani, PPD, dan pedagang besar, serta konsumen kepada pengecer.

2. Sistem pembayaran kemudian

Sistem pembayaran kemudian dilakukan antara PPD dengan petani jika PPD kehabisan modal sementara nenas belum habis terjual. Terkadang PPD membayar sebagian dari total pembelian sesuai dengan kesepakatan, lalu sisa pembayaran dilakukan setelah nenas habis terjual. Namun pemasaran nenas Bogor relatif cepat sehingga umumnya pembayaran dapat dilakukan di hari yang sama atau satu hari setelah transaksi.

3. Sistem pembayaran di muka

Sistem pembayaran di muka dilakukan oleh PPD dengan petani, hal ini terjadi karena petani telah mengambil bayaran terlebih dahulu ketika tidak ada pemasukaan saat menunggu nenas siap untuk dipanen. 


\section{Kerjasama Antar Lembaga Pemasaran}

Sebagai pihak yang saling terkait satu sama lain, lembaga pemasaran memerlukan kerjasama untuk melancarkan proses pemasaran produknya. Lembagalembaga pemasaran nenas Bogor belum melakukan kerjasama secara formal dan tertulis. Kerja sama terjadi antar lembaga pemasaran nenas yaitu kontrak antara pedagang pengumpul desa (PPD) yang menjual produknya ke pengolah dengan sebagian petani. PPD memberikan harga yang tetap sehingga meskipun harga di pasar naik atau turun, harga di tingkat petani tetap stabil. Sebagian petani bahkan membiarkan PPD melakukan kegiatan pemanenan sendiri di kebunnya atas dasar saling percaya. Kerja sama juga terjalin antara pedagang besar dengan petani atau PPD yang menjadi pemasoknya. Pedagang besar tetap menerima seluruh nenas yang dikirimkan oleh pemasok meskipun pasokan nenas sedang berlimpah. Meskipun harganya murah, pedagang besar tetap kesulitan melakukan pemasaran ketika nenas terlalu banyak. Namun dengan melakukan hal tersebut, ketika nenas sulit didapatkan pada saat tidak musim, pemasok tersebut mendahulukan untuk melakukan penjualan kepada pedagang besar langganannya tersebut. Kerja sama tersebut juga terjadi antara pengecer dengan dengan petani atau PPD untuk membuat pasokan tetap terjaga. Selain itu, terdapat praktik kolusi yang terjadi antara PPD dengan pedagang langganannya. Pedagang di pasar dapat mengetahui mana petani yang belum berpengalaman menjual produknya langsung di pasar, kemudian pedagang akan mempermainkan harga. Harga beli yang ditetapkan pedagang akan disamakan dengan harga yang beli yang ditetapkan PPD. Hal ini merugikan petani karena biaya pemasaran yang ditanggung untuk membawa nenas ke pasar jauh lebih besar dibandingkan biaya pemasaran untuk menjual ke PPD, sementara harga beli yang diterima sama. Oleh karena itu petani akan tetap memilih menjual nenas melalui PPD.

\section{Analisis Keragaan Pasar}

\section{Marjin Pemasaran}

Analisis margin pemasaran bertujuan untuk mengetahui tingkat efisiensi pemasaran nenas di Kecamatan Cijeruk. Margin pemasaran merupakan tingkat perbedaan harga antara yang diterima petani dengan yang dibayarkan oleh konsumen. Perbedaan harga disebabkan karena adanya fungsi-fungsi pemasaran yang dilakukan dengan tujuan untuk meningkatkan nilai guna atau nilai tambah sehingga konsumen puas. Nilai marjin pemasaran nenas tertinggi terdapat pada saluran 8 (petani - pedagang besar pengecer - konsumen) yaitu sebesar Rp 3 500. Pada pola saluran I, marjin pemasaran tinggi disebabkan karena pedagang besar membeli nenas dengan harga lebih rendah yaitu Rp 1 500, dijual ke pengecer dengan harga Rp 2 750, dan kemudian dijual ke konsumen akhir dengan harga Rp 5 000. Marjin terendah terdapat pada saluran 1 (petani konsumen akhir) dan 2 (petani-pengolah) yaitu sebesar Rp 0. Hal ini disebabkan karena tidak ada lembaga pemasaran yang terlibat. Secara rinci, biaya-biaya yang dikeluarkan oleh lembaga-lembaga 
pemasaran dapat dilihat pada lampiran 4. Pada kesepuluh saluran pemasaran tersebut, nilai-nilai yang ada merupakan nilai rata-rata dari kondisi normal pemasaran nenas. Artinya produksi nenas yang dipasarkan serta biaya-biaya yang dikeluarkan untuk jumlah yang berbedabeda untuk masing-masing lembaga pemasaran.

\section{Farmer's share}

Farmer's share adalah perbandingan tingkat harga yang diterima oleh petani dengan harga yang dibayarkan oleh konsumen akhir. Farmer's share merupakan konsep balas jasa atas kegiatan usahatani. Berdasarkan hasil penelitian, besarnya farmer's share petani nenas di Kecamatan Cijeruk berbeda untuk masing-masing saluran pemasaran hal ini dapat dilihat pada Lampiran 4. Farmer's share tertinggi terdapat pada saluran pemasaran 1 (petani - konsumen) dan saluran pemasaran 2 (petani - pengolah) yaitu sebesar 100 persen, sedangkan farmer's share terendah terdapat pada saluran pemasaran 8 (petani - pedagang besar - pengecer konsumen) yaitu sebesar $30 \%$. Perbedaan farmer's share yang terjadi pada setiap saluran pemasaran dikarenakan adanya perbedaan harga yang diterima setiap lembaga pemasaran, jumlah lembaga pemasaran yang terlibat, serta fungsi-fungsi yang dilakukan sehingga meningkatkan harga di tingkat konsumen.

\section{Analisis Rasio Keuntungan Terhadap Biaya.}

Salah satu alat ukur efisiensi pemasaran adalah dengan melihat besarnya rasio keuntungan atas biaya yang terbentuk pada masing-masing saluran pemasaran. Rasio keuntungan atas biaya digunakan untuk melihat sebaran keuntungan dan biaya yang dikeluarkan oleh lembaga pemasaran. Berdasarkan rasio keuntungan atas biaya, pola saluran pemasaran 1 (petani - konsumen) memiliki nilai rasio keuntungan atas biaya paling tinggi yaitu 16,3; sedangkan pola saluran pemasaran 5 (petani - PPD pengolah) nilai rasio keuntungan atas biaya rendah yaitu dengan nilai 0,43. Informasi tersebut dapat dilihat pada Lampiran 5.

\section{Analisis Efisiensi Pemasaran}

Efisiensi pemasaran merupakan tujuan akhir yang ingin dicapai dalam suatu proses pemasaran. Efisiensi pemasaran dapat tercapai apabila sistem pemasaran yang dijalankan memberikan kepuasan kepada pelaku-pelaku pemasaran yang terlibat di dalamnya seperti petani, lembaga pemasaran, dan konsumen akhir. Efisiensi pemasaran diukur dengan melihat nilai marjin pemasaran, farmer's share dan rasio keuntungan atas biaya. Selain itu, pelaksanaan fungsifungsi pemasaran, struktur pasar yang terbentuk, dan perilaku pasar juga mencerminkan efisiensi pemasaran. Berdasarkan hasil penelitian nilai efisiensi pemasaran nenas dapat dilihat pada Lampiran 6. 


\section{SIMPULAN DAN SARAN \\ Simpulan}

Berdasarkan hasil penelitian mengenai sistem pemasaran nenas Bogor di Kecamatan Cijeruk Kabupaten Bogor, dapat disimpulkan beberapa hal yaitu:

1. Saluran pemasaran nenas Bogor di Kecamatan Cijeruk terdiri atas 10 saluran pemasaran. Saluran pemasaran yang paling banyak dipilih oleh petani nenas Bogor di kecamatan Cijeruk adalah saluran pemasaran yang melibatkan pedagang pengumpul desa (PPD). Mayoritas petani memilih menjual ke PPD karena lebih mudah dan terjamin. Beberapa petani menjual langsung kepada pedagang besar dan pengecer karena petani tersebut memiliki fasilitas pengangkutan yang memadai. Selain itu, terdapat petani yang menjual langsung kepada konsumen akhir dan pengolah.

2. Berdasarkan hasil analisis yang telah dilakukan, saluran pemasaran 3 (petani - PPD - konsumen) merupakan saluran pemasaran yang relatif lebih efisien untuk pemasaran dengan tujuan konsumen. Untuk tujuan pengolah, saluran 6 (petani - PPD Pengolah) merupakan saluran yang relatif lebih efisien. Keduanya merupakan saluran yang paling diminati dari 10 saluran tersebut.

\section{Saran}

Berdasarkan hasil penelitian, saran yang dapat direkomendasikan bagi petani nenas di Kecamatan Cijeruk yaitu: dalam jangka pendek petani dapat melakukan pemasaran yang pada pola saluran 3 dan 6 karena saluran ini relatif lebih efisien jika dibandingkan dengan saluran yang lainnya. Dalam jangka panjang, kelompok tani sebaiknya memaksimalkan fungsinya dan membantu petani untuk meningkatkan posisi tawar petani terhadap PPD sehingga petani dapat meningkatkan pendapatan. Kelompok tani dapat mengembangkan kemampuan petani dalam mengelola usaha secara efisien dan menguntungkan menuju kemandirian sesuai dengan tujuan awal didirikannya kelompok tani, misalnya melakukan pengembangan produk dengan mengolah sendiri nenas menjadi selai atau asinan sehingga akan meningkatkan nilai jual seperti yang pernah dilakukan tahun-tahun sebelumnya. Hal tersebut juga dapat mencegah nenas terbuang ketika panen raya tiba.

\section{DAFTAR PUSTAKA}

[BPS] Badan Pusat Statistik. 2008. Kabupaten Bogor dalam Angka 2009. Bogor (ID): BPS.

[BPS] Badan Pusat Statistik. 2009. Kabupaten Bogor dalam Angka 2010. Bogor (ID): BPS.

[BPS] Badan Pusat Statistik. 2010. Kabupaten Bogor dalam Angka 2011. Bogor (ID): BPS

[BPS] Badan Pusat Statistik. 2011. Kabupaten Bogor dalam Angka 2012. Bogor (ID): BPS

[BPS] Badan Pusat Statistik. 2012. Kabupaten Bogor dalam Angka 2013. Bogor (ID): BPS

Adelina. 2014. Analisis perilaku lembaga pemasaran ikan mas di Kabupaten Pasaman Sumatera Barat [skripsi]. 
Bogor (ID): Institut Pertanian Bogor.

Asmarantaka, Ratna W. 2012. Pemasaran Agribisnis. Bogor (ID): IPB-Press.

Carolan, Michael. 2012.The Sociology of Food and Agriculture. Oxon (UK): Routledge.

Downey, W. David., Kohls, Richard L. 1972. Marketing of Agricultural Products. New York (US): Macmillan Company

Keller, Kevin Lane., Kotler, Philip. 2008. Manajemen Pemasaran. Jakarta (ID): Erlangga.

Giroh DY, Umar HY, Yakub W. 2010. Structure, conduct and performance of farm gate marketing of natural rubber in Edo and Delta States, Nigeria. African Journal of Agricultural Research. 5(14): 1780-1783. DOI: 10.5897/AJAR09.356

Hadianti, Sri., Indriyani, Ni Luh Putu. 2008. Petunjuk Teknis Budidaya Nenas. Solok (ID): Balai Penelitian Tanaman Buah Tropika.

Soekartawi. 1991. Agribisnis: Teori Dan Aplikasinya. Jakarta (ID): Rajawali Pers.

Soekartawi. 2002. Prinsip Dasar Ekonomi Pertanian. Jakarta (ID): Rajawali Pers.

Herawati. 2012. Analisis tataniaga nenas palembang kasus Desa Paya Besar, Kecamatan Parayaman, Kabupaten
Ogan Ilir, Provinsi Sumatera Selatan [skripsi]. Bogor (ID): Institut Pertanian Bogor.

Muslim E, Evertina V, Nurcahyi R. 2008. Structure, conduct, and performance analysis in palm cooking oil industry in Indonesia using structure conduct performance paradigm (SCP). International Seminar on Industrial Engineering and Management [Internet]. [2008 Oktober 25]. Jakarta (ID): UI Press. Hlm 40-46; [Diunduh pada Juni 2015]. Tersedia pada: http://staff.ui.ac.id/system/files/us ers/erlinda.muslim/publication/str uctureconductandperformanceanal ysisinpalmcookingoilindustryinind onesiausingstructureconductperfor .pdf.

Rahmawati. 2013. Analisis efisiensi pemasaran nenas studi kasus di Desa Cipelang, Kecamatan Cijeruk, Kabupaten Bogor [skripsi]. Bogor (ID): Institut Pertanian Bogor.

Sihombing. 2010. Analisis sistem tataniaga nenas bogor studi kasus Desa Cipelang, Kecamatan Cijeruk, Kabupaten Bogor [skripsi]. Bogor (ID): Institut Pertanian Bogor. 
Lampiran 1. Gambar Pola Saluran Pemasaran Nenas di Kecamatan Cijeruk

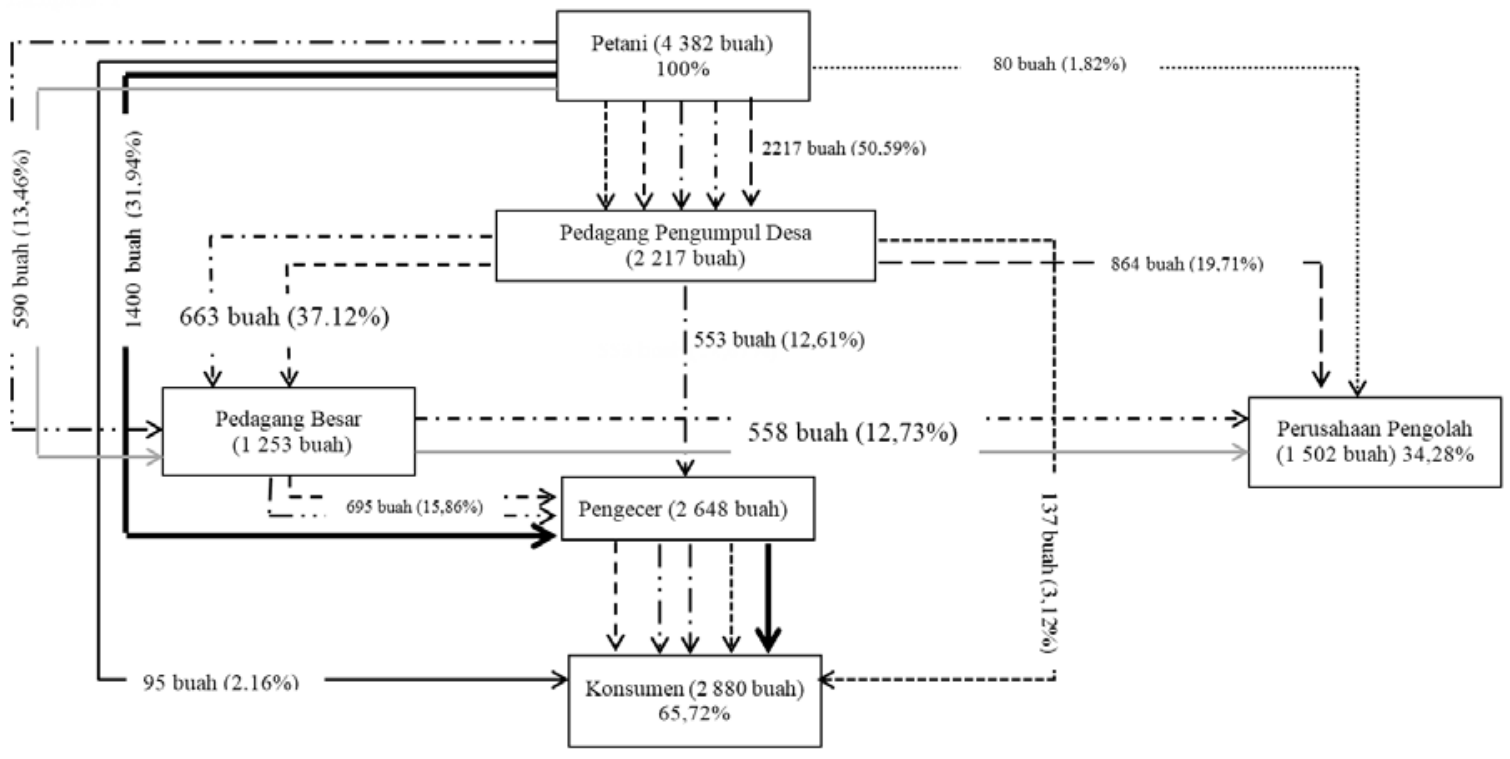

Keterangan

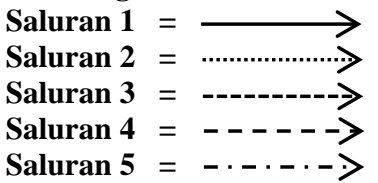

Saluran $6=---\rightarrow$

Saluran $7=-\cdot-\rightarrow$

Saluran $8=-\cdots-\cdots$

Saluran $9=$

Saluran $10=$

Lampiran 2. Fungsi Pemasaran yang Dilakukan oleh Lembaga Pemasaran

\begin{tabular}{|c|c|c|c|c|c|}
\hline \multirow[b]{2}{*}{ Fungsi Pemasaran } & \multicolumn{4}{|c|}{ Lembaga Pemasaran } & \multirow[b]{2}{*}{ Pengolah } \\
\hline & Petani & PPD & $\begin{array}{c}\text { Pedagang } \\
\text { Besar }\end{array}$ & Pengecer & \\
\hline \multicolumn{6}{|l|}{ Fungsi Pertukaran } \\
\hline Pembelian & - & $\sqrt{ }$ & $\sqrt{ }$ & $\sqrt{ }$ & $\sqrt{ }$ \\
\hline Penjualan & $\sqrt{ }$ & $\sqrt{ }$ & $\sqrt{ }$ & $\sqrt{ }$ & $\sqrt{ }$ \\
\hline \multicolumn{6}{|l|}{ Fungsi Fisik } \\
\hline Pengemasan & - & - & - & $\sqrt{ }$ & $\sqrt{ }$ \\
\hline Pengangkutan & - & $\sqrt{ }$ & - & $\sqrt{ }$ & - \\
\hline Penyimpanan & घ & $\sqrt{ }$ & घ & $\sqrt{ }$ & $\sqrt{ }$ \\
\hline Pengolahan & - & - & - & - & $\sqrt{ }$ \\
\hline \multicolumn{6}{|l|}{ Fungsi Fasilitas } \\
\hline Sortir & $\sqrt{ }$ & घ & - & $\sqrt{ }$ & - \\
\hline Risiko & $\sqrt{ }$ & - & - & - & - \\
\hline Pembiayaan & $\sqrt{ }$ & $\sqrt{ }$ & $\sqrt{ }$ & $\sqrt{ }$ & $\sqrt{ }$ \\
\hline Informasi Pasar & $\sqrt{ }$ & $\sqrt{ }$ & $\sqrt{ }$ & $\sqrt{ }$ & $\sqrt{ }$ \\
\hline
\end{tabular}

Keterangan:

$\sqrt{ } \quad$ : Dilakukan

- : Tidak dilakukan

- : Kadang-kadang 
Lampiran 3. Karakteristik Perilaku Pasar

\begin{tabular}{|c|c|c|c|}
\hline \multirow[b]{2}{*}{$\begin{array}{c}\text { Lembaga } \\
\text { Pemasaran }\end{array}$} & \multicolumn{3}{|c|}{ Praktik Perilaku Pasar } \\
\hline & $\begin{array}{c}\text { Pembelian \& } \\
\text { Penjualan }\end{array}$ & Penentuan Harga & $\begin{array}{c}\text { Kerja sama } \\
\text { antarlembaga }\end{array}$ \\
\hline PPD & $\begin{array}{l}\text { - } \text { PPD membeli nenas } \\
\text { dari petani } \\
\text { langganannya. } \\
\text { - PPD dapat membeli } \\
\text { di kebun, diantarkan } \\
\text { oleh petani, atau } \\
\text { bahkan memanen } \\
\text { sendiri. } \\
\text { - Biaya pengangkutan } \\
\text { ditanggung oleh } \\
\text { petani. }\end{array}$ & $\begin{array}{l}\text { - Harga ditentukan } \\
\text { oleh PPD meskipun } \\
\text { dan jarang ada } \\
\text { dinegosiasi. } \\
\text { - Pembayaran ada } \\
\text { yang dilakukan di } \\
\text { muka, langsung, } \\
\text { sebagian, atau } \\
\text { setelah produk } \\
\text { terjual. }\end{array}$ & $\begin{array}{l}\text { - Petani menanyakan } \\
\text { informasi harga nenas } \\
\text { kepada PPD. } \\
\text { - PPD yang menjual } \\
\text { nenas ke pengolah } \\
\text { membuat kotrak } \\
\text { dengan petani } \\
\text { sehingga harga stabil } \\
\text { saat panen raya. }\end{array}$ \\
\hline $\begin{array}{l}\text { Pedagang } \\
\text { Besar }\end{array}$ & $\begin{array}{l}\text { - } \text { Membeli nenas dari } \\
\text { petani atau PPD. } \\
\text { - } \text { Barang diantar oleh } \\
\text { penjual ke pasar dan } \\
\text { dijual ke pengecer } \\
\text { di tempat yang } \\
\text { sama. } \\
\text { - Produk yang dijual } \\
\text { ke pengolah diantar } \\
\text { oleh pedagang } \\
\text { besar. }\end{array}$ & 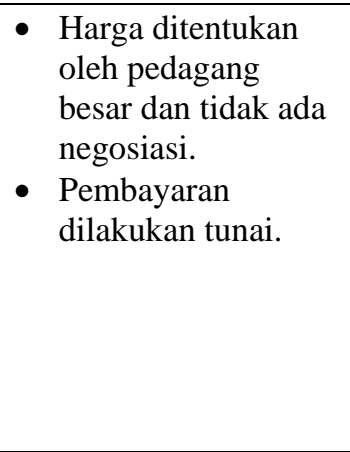 & $\begin{array}{l}\text { Pedagang besar tetap } \\
\text { membeli nenas } \\
\text { meskipun sedang } \\
\text { panen raya, sehingga } \\
\text { saat nenas langka } \\
\text { penjual tetap loyal. }\end{array}$ \\
\hline Pengecer & $\begin{array}{l}\text { - } \text { Membeli nenas dari } \\
\text { petani, PPD, atau } \\
\text { pedagang besar. }\end{array}$ & $\begin{array}{ll}\text { - } & \text { Kesepakatan antara } \\
\text { pengecer dengan } \\
\text { konsumen. } \\
\text { - }\end{array}$ & $\begin{array}{l}\text { - } \text { Beberapa pengecer } \\
\text { bekerja sama dengan } \\
\text { PPD agar pasokan } \\
\text { tetap terjaga. }\end{array}$ \\
\hline
\end{tabular}


Lampiran 4. Farmer's Share pada Saluran Pemasaran Nenas di Kecamatan Cijeruk

\begin{tabular}{crrr}
\hline Saluran Pemasaran & $\begin{array}{c}\text { Harga di tingkat } \\
\text { petani (Rp/buah) }\end{array}$ & $\begin{array}{c}\text { Harga di tingkat } \\
\text { konsumen } \\
\text { (Rp/buah) }\end{array}$ & $\begin{array}{c}\text { Farmer's share } \\
\text { (\%) }\end{array}$ \\
\hline 1 & 5625 & 5625 & 100.00 \\
2 & 2000 & 2000 & 100.00 \\
3 & 1785 & 3000 & 59.50 \\
4 & 1785 & 5500 & 32.45 \\
5 & 1785 & 2750 & 64.90 \\
6 & 1785 & 2475 & 72.12 \\
7 & 1785 & 5000 & 35.70 \\
8 & 1500 & 5000 & 30.00 \\
9 & 1500 & 2750 & 54.54 \\
10 & 2250 & 5000 & 45.00 \\
\hline
\end{tabular}

Lampiran 5. Rasio Keuntungan terhadap Biaya Pemasaran Nenas di Kecamatan Cijeruk

\begin{tabular}{|c|c|c|c|c|c|c|c|c|c|c|}
\hline \multirow{2}{*}{$\begin{array}{c}\text { Lembaga } \\
\text { Pemasaran }\end{array}$} & \multicolumn{10}{|c|}{ Saluran Pemasaran } \\
\hline & 1 & 2 & 3 & 4 & 5 & 6 & 7 & 8 & 9 & 10 \\
\hline \multicolumn{11}{|l|}{ Petani } \\
\hline $\mathrm{Li}$ & 5300 & 1600 & 1627.5 & 1627.5 & 1627.5 & 1627.5 & 1627.5 & 1310 & 1310 & 1835 \\
\hline $\mathrm{Ci}$ & 325 & 400 & 157.5 & 157.5 & 157.5 & 157.5 & 157.5 & 190 & 190 & 415 \\
\hline $\mathrm{Li} / \mathrm{Ci}$ & 16.3 & 4 & 10.33 & 10.33 & 10.33 & 10.33 & 10.33 & 6.89 & 6.89 & 4.42 \\
\hline \multicolumn{11}{|l|}{ PPD } \\
\hline $\mathrm{Li}$ & & & 1048.57 & 402.32 & 402.32 & 356.66 & 730.63 & & & \\
\hline $\mathrm{Ci}$ & & & 166.43 & 312.68 & 312.68 & 333.34 & 234.37 & & & \\
\hline $\mathrm{Li} / \mathrm{Ci}$ & & & 6.3 & 1.28 & 1.28 & 1.06 & 3.11 & & & \\
\hline \multicolumn{11}{|l|}{ Pedagang } \\
\hline \multicolumn{11}{|l|}{ Besar } \\
\hline $\mathrm{Li}$ & & & & 233.33 & 50 & & & 233.33 & 1050 & \\
\hline $\mathrm{Ci}$ & & & & 16.67 & 200 & & & 16.67 & 200 & \\
\hline $\mathrm{Li} / \mathrm{Ci}$ & & & & 13.99 & 0.25 & & & 73.98 & 5.25 & \\
\hline \multicolumn{11}{|l|}{ Pengecer } \\
\hline $\mathrm{Li}$ & & & & 2293.57 & & & & & & \\
\hline $\mathrm{Ci}$ & & & & 456.43 & & & & & & \\
\hline $\mathrm{Li} / \mathrm{Ci}$ & & & & 5.02 & & & & & & \\
\hline $\begin{array}{l}\text { Total Rasio } \\
\text { Li/Ci }\end{array}$ & 16.3 & 4 & 8.26 & 0.43 & 4.04 & 4.04 & 7.46 & 9.99 & 6.05 & 7.31 \\
\hline
\end{tabular}


Lampiran 6. Nilai Efisiensi Pemasaran pada Masing-Masing Saluran Pemasaran Nenas di Kecamatan Cijeruk

\begin{tabular}{lrrrrr}
\hline $\begin{array}{c}\text { Saluran } \\
\text { pemasaran }\end{array}$ & $\begin{array}{c}\text { Harga jual } \\
\text { (Rp/buah) }\end{array}$ & $\begin{array}{c}\text { Total biaya } \\
\text { (Rp/buah) }\end{array}$ & $\begin{array}{c}\text { Marjin } \\
\text { (\%) }\end{array}$ & FS (\%) & $\square$ C \\
\hline Saluran 1 & 5625 & 325.00 & 0 & 100 & 16.3 \\
Saluran 2 & 2000 & 400.00 & 0 & 100 & 4.00 \\
Saluran 3 & 1785 & 323.93 & 40,5 & 59.50 & 8.26 \\
Saluran 4 & 1785 & 456.43 & 50.00 & 32.45 & 4.83 \\
Saluran 5 & 1785 & 670.18 & 35,09 & 64.90 & 0.43 \\
Saluran 6 & 1785 & 490.84 & 27.87 & 72.12 & 4.04 \\
Saluran 7 & 1785 & 578.54 & 64.3 & 35.70 & 7.64 \\
Saluran 8 & 1500 & 454.77 & 70.00 & 30.00 & 9.99 \\
Saluran 9 & 1500 & 390.00 & 45.45 & 54.54 & 6.05 \\
Saluran 10 & 2250 & 601.67 & 55.00 & 45.00 & 7.31 \\
\hline
\end{tabular}


Murni Anggraeni, dan Suharno 